\title{
The Factor Influencing Organizational Citizenship Behavior of Employees in Private Universities in South Sumatera Province
}

\author{
Desi Ulpa Anggraini \\ Sekolah Tinggi Ilmu Ekonomi Rahmaniyah \\ E-mail: desi.ulpa22@gmail.com \\ Wibowo \\ Universitas Prof. Dr. Moestopo (Beragama) \\ Hanes Riyadi \\ Institut Bisnis dan Informasi Kwik Kian Gie \\ Husein Umar \\ Institut Bisnis dan Informasi Kwik Kian Gie
}

Received: Nov. 11, 2018 Accepted: December 24, 2018 Published: June 17, 2019

doi:10.5296/bms.v10i1.14038ＵRL: https://doi.org/10.5296/bms.v10i1.14038

\begin{abstract}
The objectives of this study is to analyze the factors affecting Organizational Citizenship Behavior (OCB) Nonacademic Employees in Private Universities in South Sumatra. The research design used in the study is explanatory design which explains the causal relationship among variables and scoring all indicators for each variables. The study location is in South Sumatra Province while the research objects are 13 Private Universities with 200 nonacademic employees as respondents. This dissertation used primary data from questionnaire filled out by the respondents. The sample selection used simple random
\end{abstract}




\section{Macrothink}

sampling. The method of research used descriptive statistics using SPSS and Structural Equation Modeling (SEM). The descriptive analysis shows that the level of OCB, Work Satisfaction, Transformation Leadership, Work Motivation, and Organization Culture are at a positive level. The results of relationship among variables stated that the Transformational Leadership has no significant impact on OCB, Work Motivation has significant impact on OCB, Organization Climate has significant impact on OCB, Work Motivation has significant impact on Work Satisfaction, Organization Climate has significant impact on Work Satisfaction, Transformational Leadership has significant impact on Work Satisfaction, Transformational Leadership has no significant impact on Work Motivation, Organization Climate has significant impact on Work Motivation, and Work Satisfaction has significant impact on OCB.

Keywords: OCB, satisfaction, leadership, motivation, climate 


\section{Introduction}

One of psychology that plays role in human resources management is organizational citizenship behavior (OCB). OCB is a helpful attitude shown by organization' members, which is constructive, appreciated by the company but it isn't directly related to individual productivity (Bateman \& Organ in Mehboob, Bhutto, 2012). A success organization needs employees who will do more than their formal tasks and want to give performance beyond expectation. In today's dynamic world of work, where the task is always done in a team, flexibility is the most important. Organization wants its employees are ready to the tasks which are not stated in their job descriptions. According to Robbins and Judge (2007), the fact shows that an organization which has employees with good OCB' quality, will have better performance in organization.

Based on some research showed that the employees' OCB enhancement can be triggered by job satisfaction, where this satisfaction is affected by some factors such as transformational leadership, motivation and organizational climate.

Transformational leadership is a leader's behavior which is able to motivate employees to work harder and want to work more than what they should do to be able to make changes and achieve goals. Some previous studies conclude that transformational leadership has significant positive effect toward employees' job motivation (Chen, 2004; Mariatni, 2007; Anoop and Lokman, 2009). Bass in Purvanova et al (2006) states that transformational leadership can make employees be more involved and caring on their jobs, give more attention and time to their jobs, and less attention to their personal interests.

Besides transformational leadership style, job satisfaction is also affected by job motivation factor, in line with the research result of Motevalli and Chevalier (2015). His research findings showed that job motivation is very significant where the salary is the factor that influence the most important motivation. By increasing the employees' job motivation so they will be happy and have higher job satisfaction.

Many research have been done related to organizational climate, satisfaction and employees' commitment. Research on business company done by Castro and Martin (2010) which has tested the relationship of organizational climate and job satisfaction in an information and technology organization in South Africa. Research findings showed that 9 of 12 organizational climate dimensions showed strong positive relationship toward job satisfaction variable.

University is an open organization in running their activity process involves and are affected by many elements, either the elements inside or the elements outside. In order to get clarity about the problem and its causes, need to be revealed through elements related to the quality of higher education institutions. In the universities environment, there are two important elements in supporting college goals and mission from the human resource side, those are lectures and administration staff. The lectures will help in improving the quality of students' resources, while the administrative staff play a key role in the student's service process. The 
performance of these two elements are able to affect universitycompetitive advantagelevel to be able to win the competition.

Private universities in South Sumatera whose its guidance below the ministry of research, technology and Universities Kementerian Riset, Teknologi, dan Pendidikan Tinggi Republik Indonesia and in this case under control of "kopertis wilayah 2" which is as an extension hand of the ministry of research, technology and university in doing supervision, controlling, and guiding to the private universities of three provinces, those are: South Sumatera province, Lampung province, Bengkulu province. Research objects will be studied are the employees of the administrative headquarters only at 13 private universities in South Sumatera, those are: PGRI, Baturaja, IBA, Kader Bangsa, Muhammadyah, Bina Darma, Syahyakirti, Tamansiswa, Tridinanti, Islam OKI, IGM, Musi Rawas, Katholik Musi Charitas, dan universitas Palembang.

Based on the problems above, so this research was conducted by using five variables, those are: transformational leadership style, job motivation, and organizational climate as the factors affected job satisfaction and organizational citizenship behavior of the administrative headquarters employees at private universities in South Sumatera Province.

\section{Literature Review}

The Organ (2006) states that Organizational Citizenship Behavior (OCB) as individual behavior that is discretionary, not directly or explicitly recognized by the formal reward system, and that in the aggregate promotes the effective functioning of the organization. But the most commonly used dimension to conceptualize OCB is the dimensions are developed by Organ (2006). According to Organ et al. (2006) there are five OCB dimensions, those are as follow: 1.Altruism, 2.Civic virtue, 3.Conscientiousness, 4. Courtesy, 5. Sportsmanship.

Job satisfaction, according to Mathis and Jackson (2003) is employee's emotional condition where there is or there is no interaction between the value repayment of employee's services from the company with the level of the value of the remuneration that is desired by the employees concerned, it can be financial or non-financial. The dimension of job satisfaction according to Smith, Kendall \& Hulin (1969) and Luthan (2006) there are some that can be used to reveal the important characteristics of work, where the people are able to respond. These dimensions are: 1) Work itself, 2) Supervision, 3). Co-Workers,4). Promotion, 5). Pay.

Robbins \& Judge (2007) states that Transformational leadership inspire followers to transcend their own self-interest and who are capable of having a profound and extraordinary effect on follower. The impact is profound and extraordinary on these followers reflected on positive behavior that is shown at work environment so are be able to support an organization or company to reach its goal effectively. Robbins \& Judge (2007) and Northouse (2005) states transformational leadership dimension, those are: 1) idealize influence, 2) inspirational motivation, 3) intellectual stimulation, 4) individualize consideration.

Motivation is a psychological condition from the interaction result between employees' needs 
and external factor that affect an employee's behavior (Danim, 2004).According to George and Jones (2005) states that there are three indicators in job motivation, those are: 1). Direction of behavior, referring to behavior that people choose when they work, 2). Level of effort, referring to how hard a person attempt in working, 3). Level of persistence, focus on someone's mental in facing problem.

While the concept of organizational climate according to Richard M. Hodgetts (2002) "Human relations is the process by which management and workers interact and attain their objectives”. Stringer (2002) states the six of organizational climate dimension, such as: 1). structure, 2). Standards, 3). Responsibility, 4). Recognition, 5). support, 6). Commitment.

\section{Research Method}

This research methodology aimed to get complete, profound, and credible data. Research methodology was used in this research is depended on research goals which have been stated before. To answer the research goals those are to know the influence of leadership (X1), job motivation (X2), organizational climate (X3) toward job satisfaction (Y1) and Organizational Citizenship Behavior (OCB) (Y2) of private universities' employees in South Sumatera province by using verificative research methodology that has systematically test goal about some allegations related to relationship between variables and problems are being investigated in the hypothesis. Hypothesis will be tested by path analysis for research hypothesis testing, so the determination steps and operational variables, formulation of hypothetical test, type's determination and research model analysis.

Population in this research spreads out in thirteen universities with the total number of it was 517 persons, while sample was taken related to Hair et al' opinion (2010) that the number of sample that was taken from population can be decided by determining 5 - 10 times of total variable used in an analysis design, and at least 200 samples. According to Hairs et al (2010), the number of universities' employees' sample that was observed is 200 persons. While for sampling technique used proportionate simple random sampling.

Technique for collecting the data in this research used communication and questionnaire filling. Questionnaire was distributed to the employees of administrative headquarters and interview was done to the employees of administrative headquarters and universities' leaders and related parties in a university.

Questionnaire instrument testing was done by using validity and reliability test. Validity shows the extent of the score/value/size which is obtained really states the measurement/observation result that will be measured its validity generally questionable regarding the result of psychological or non - physical. Related to psychological characteristics, the measurement results obtained are actually expected to describe or to give score/value of another characteristics that will be main concern.

Validity is generally classified into three major categories, those are content validity, criterion-related validity and construct validity. In this research will be discussed it concerns 
validity to test whether the question has measured the same aspect. So that in this research construct validity was used. Reliability is an index indicates the extent to which a measuring device is reliable. Every measuring devices should has capability to give measurement result are relatively consistent over time.

Validity testing process was done by using minimum data testing of 30 respondents. Because of the sum contains elements of each question, so its correlation result must be corrected first. Then, the correlation result was compared by correlation value at Correlation Product Moment table. If correlation value of counting result is more than correlation value table, so the questions are valid, and vice versa.

After questionnaire is declared valid, questionnaire testing are continued to reliability testing. Measuring tool was used is Cronbach's Alpha test. If the value of Cronbach's Alpha counting result is higher than 0.7 (Nunnally, 1978) so the questionnaire is reliable.

Analytical tools used consists of two, those are (1) An analytical tool to describe research variables through indicators, dimensions and variables using descriptive statistical method those are average and percentage, (2) Analysis tool for testing research hypothesis by using Structural Equation Modeling (SEM) method.

In an average analysis, measurement scale 1, 2, 3, 4, and 5 will be completed in form of scare range so results of analysis data can be set qualitatively at a certain range. The formula was used to determine the scale range is: $\mathrm{Rs}=(\mathrm{k}-\mathrm{m}) / \mathrm{k}$ where: $\mathrm{k}$ is the largest scale value, $\mathrm{m}$ is the smallest scale value $=4 / 5$ or 0.8 . So that, the measurement scale ranges are: (1) $1-$ $1.80=$ strongly disagree/worst, (2) $>1.80-2.60=$ disagree/worse, (3) $>2.60-3.40$ $=$ doubtful/disagree, $(4)>3.40-4.20=$ agree/good, $(5)>4.20-5.00=$ strongly agree/very good.

For the company, if each dimensions has no positive average or disagree that is the average range value under 3.40, so it's problematic dimension and need to be followed up. By using Delphi technique (Husein, 2005) the value of measurement scale 1, 2, and 3 of each indicators, is gained a minimum cumulative percentage $68 \%$ so those indicators will be problem for a company so it need to be followed up. Besides quantitative analysis with questionnaire data, this descriptive study also comes with qualitative exposure toward problematic result analysis. Qualitative exposure will be supported by primary data of a part of respondents interview result.

SEM structural equation model involves a number of systematic symbols. It can be seen such as in LISREL software package was used in this research. Research structure model used complete indicators, symbols, and these explanations can be seen in figure below. 


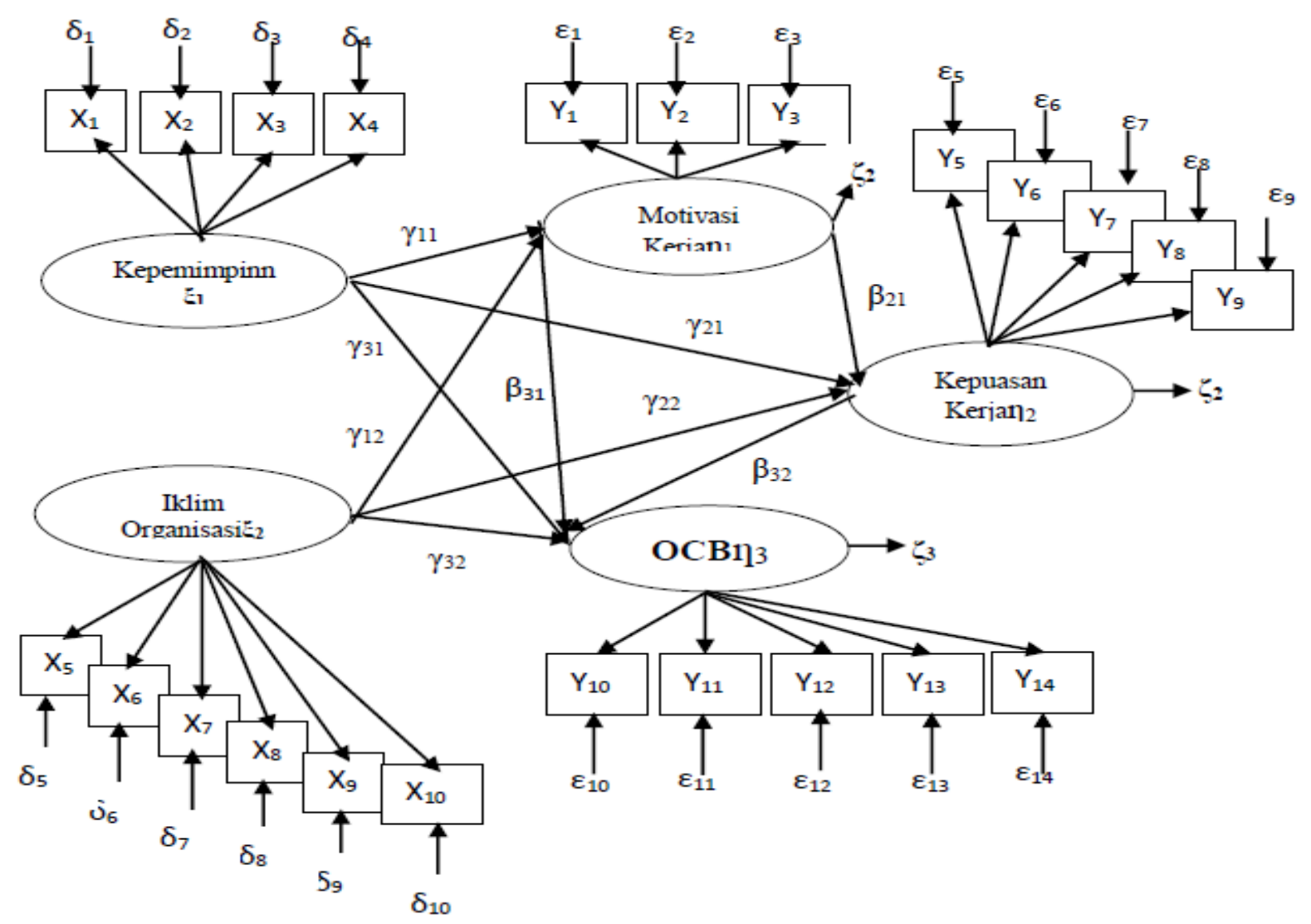

Based on this complete research model, then it can be set structural model and measurement model. Structural equation is an equation which states the relationship between indicator variables and latent indicators.

a. The equations of Structural Model:

$\eta_{1}=\gamma_{11} \xi_{1}+\gamma_{12} \xi_{2}+\zeta_{1}$

$\eta_{2}=\gamma_{21} \xi_{1}+\gamma_{22} \xi_{2}+\beta_{21} \eta_{1}+\zeta_{2}$

$\eta_{3}=\gamma_{32} \xi_{2}+\gamma_{31} \xi_{1+} \beta_{31} \eta_{1}+\beta_{32} \eta_{2}+\zeta_{3}$

b. The equations of Measurement Model:

$\mathrm{X}=\lambda_{\mathrm{x}} \xi+\delta$

\section{Discussion}

Picture 4.1. is a computer output in basic model estimates that is a complete output (hybrid) that describes great influence between all latent variable and observed variable, and between latent variable and others latent variables.

Picture 4.1.Complete Model of Research Findings 


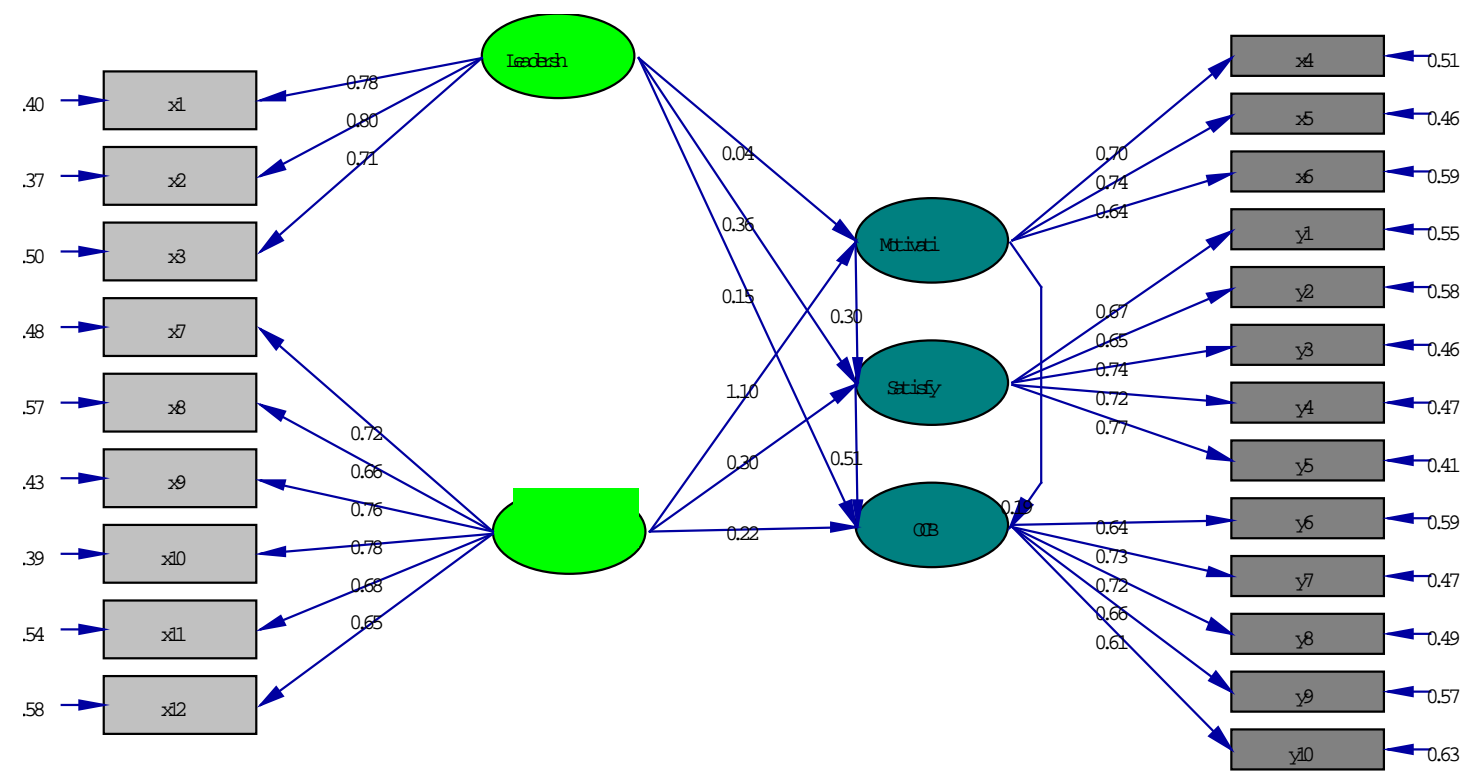

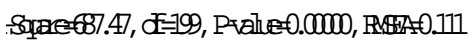

Picture 4.2. is a computer output in t statistic value (basic model T-values) that is a complete output (hybrid) that describes significant level whether great influence between all latent variables toward observed variable, and latent variable's influence toward other latent variables are significant or not.

Picture 4.2.Complete Model (t statistic value)

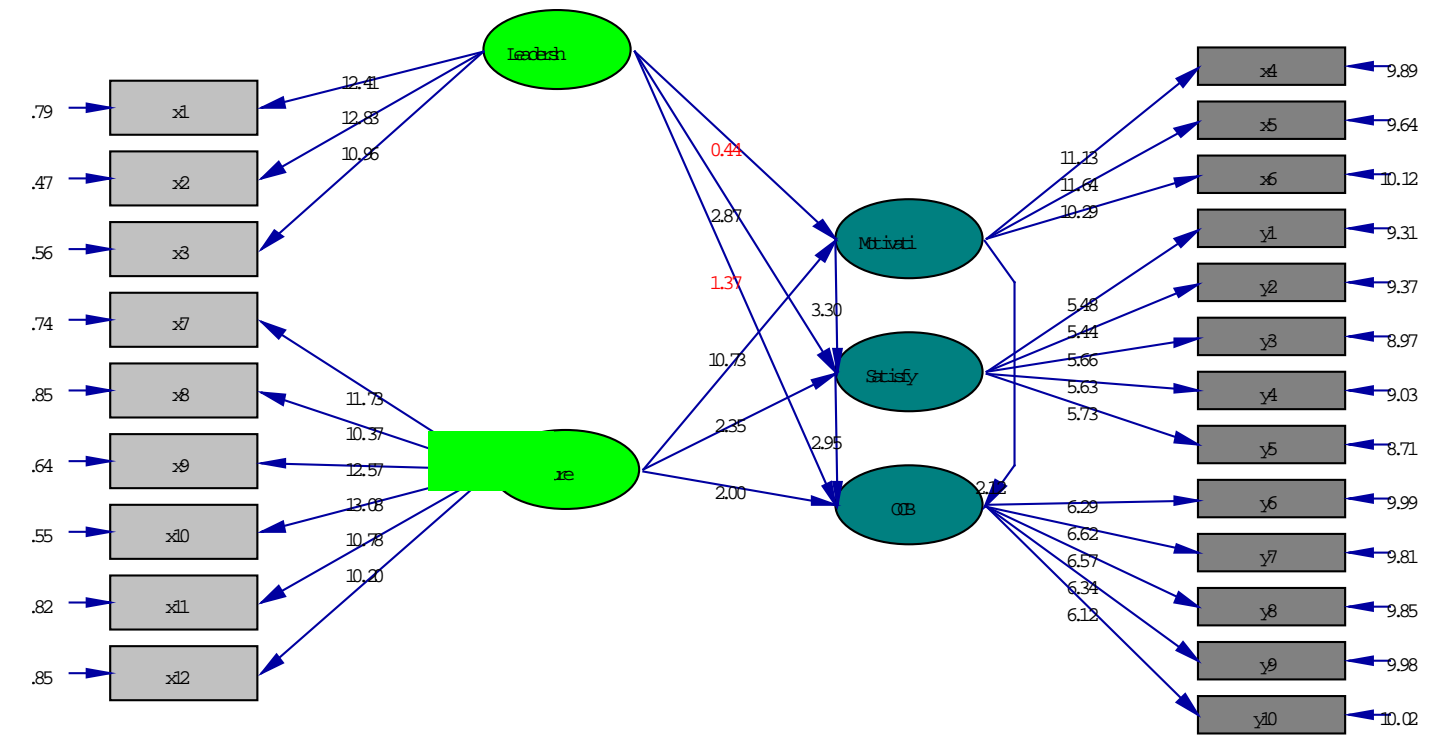

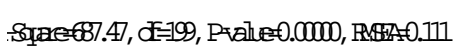

For analysis needs, two pictures above are simplified for research goals and research model, as in picture 4.3.that show great influence among variables and picture 4.4 shows t statistic value (T-values). 


\section{Macrothink}

Picture 4.3.Great Influence among variables

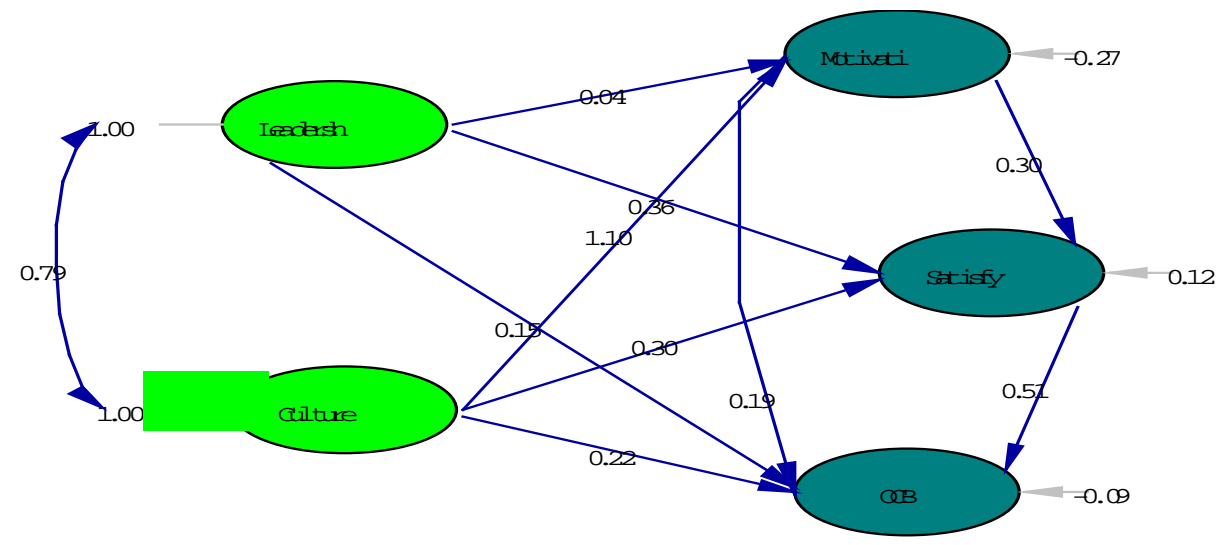

OPIII

Picture 4.4.T Statistic Value

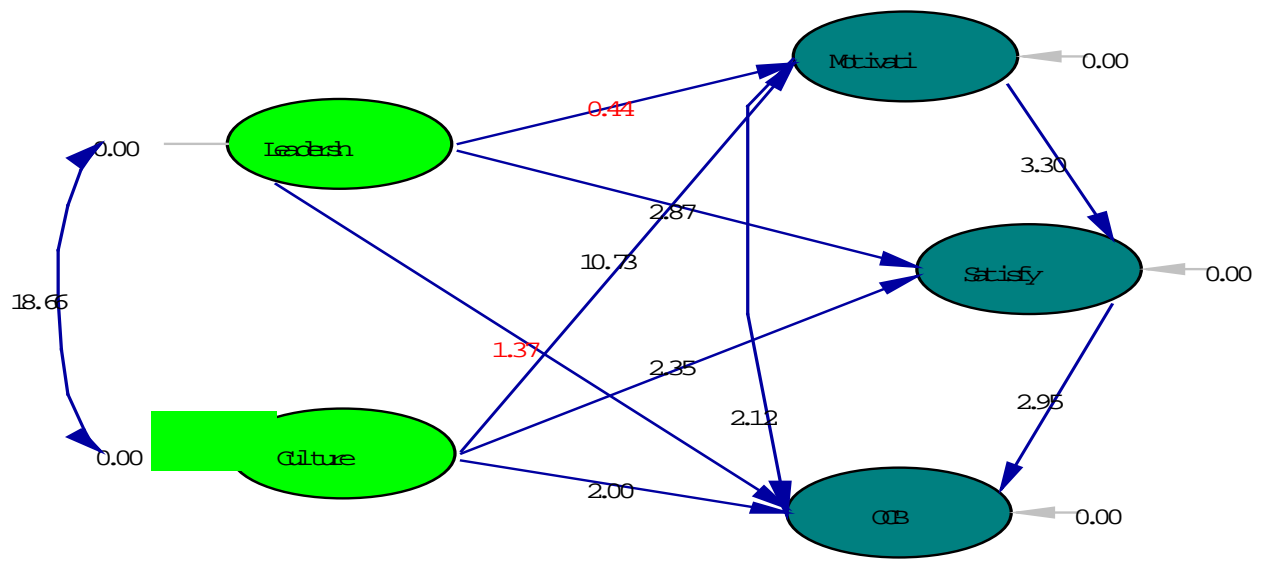

OPOCIII

Based on influence value and $\mathrm{t}$ - distribution value of one variable to the other variables as in picture 4.3 and picture 4.4 can be known the influences among variables in table 4.1 
Table 4.1. Great Influence among Variables

\begin{tabular}{|l|c|c|c|}
\hline \multicolumn{1}{|c|}{ The Influence among Variables } & $\begin{array}{c}\text { Great } \\
\text { Influence }\end{array}$ & T Value & $\begin{array}{c}\text { Influence } \\
\text { Value }\end{array}$ \\
\hline Transf Leadership. -> OCB & 0.15 & 1.37 & No effect \\
\hline Job Motivation -> OCB & 0.19 & 2.12 & Positive \\
\hline Organizational Climate-> OCB & 0.22 & 2.00 & Positive \\
\hline Job Motivation -> Job Satisfaction & 0.30 & 3.30 & Positve \\
\hline Organizational Climate -> Job Satisfaction & 0.30 & 2.35 & Positive \\
\hline Trans Leadership. -> Job Satisfaction & 0.36 & 2.87 & Positive \\
\hline Trans Leadership -> Job Motivation & 0.04 & 0.44 & No effect \\
\hline Organizational Climate -> Job Motivation & 1.10 & 10.73 & Positive \\
\hline Job Satisfaction -> OCB & 0.51 & 2.95 & Positive \\
\hline
\end{tabular}

Besides to know the influences of each variables, it can be set either direct great influence of one variable with other variables or great influence on this moderating variables in table 4.2.

Table 4.2. Great Influence on Moderating Variable

\begin{tabular}{|c|l|l|r|r|c|}
\hline No. & Plot & $\begin{array}{c}\text { Intervening } \\
\text { Variable }\end{array}$ & $\begin{array}{c}\text { Direct } \\
\text { Influence }\end{array}$ & Indirect Influence & $\begin{array}{c}\text { Total } \\
\text { Effect }\end{array}$ \\
\hline 1 & Leadership->Satisfaction & Motivation & 0.36 & $\begin{array}{c}0.04 \times 0.3= \\
0.012\end{array}$ & 0.37 \\
\hline 2 & Leadership->OCB & Motivation & 0.15 & $\begin{array}{c}0.04 \times 0.19= \\
0.01\end{array}$ & 0.16 \\
\hline
\end{tabular}




\section{Macrothink}

\begin{tabular}{|c|l|c|c|c|c|}
\hline 3 & Leadership ->OCB & $\begin{array}{c}\text { Job } \\
\text { satisfactio } \\
\mathrm{n}\end{array}$ & 0.15 & $\begin{array}{c}0.36 \times 0.51= \\
0.18\end{array}$ & 0.18 \\
\hline 4 & Climate-> OCB & Motivation & 0.22 & $1.1 \times 0.19=0.21$ & 0.43 \\
\hline 5 & Climate-> OCB & $\begin{array}{c}\text { Job } \\
\text { Satisfactio } \\
\mathrm{n}\end{array}$ & 0.22 & $0.3 \times 0.51=0.15$ & 0.37 \\
\hline
\end{tabular}

Besides in table form, influence value and t distribution value in the picture form can be seen on picture 4.5 .

Picture 4.5. Basic Model of Research Findings

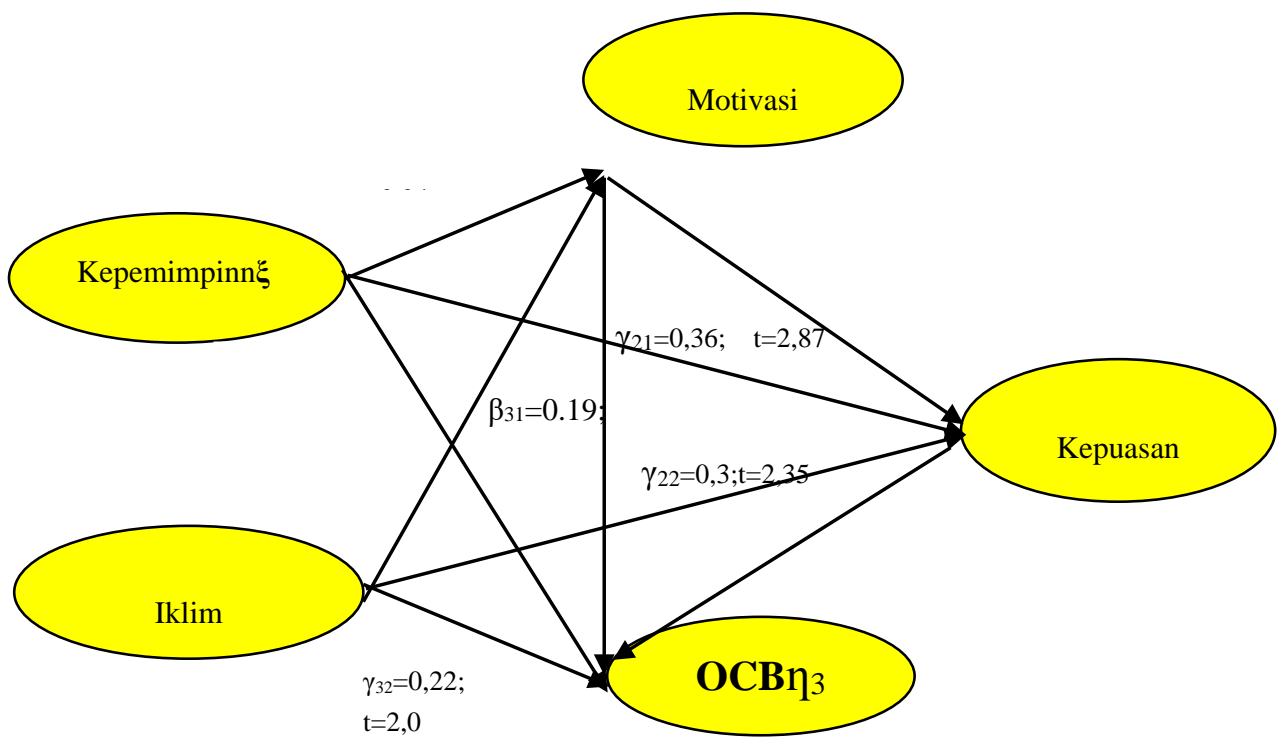

Based on table 48 or picture 4.5 can be known the great influence between latent variables both directly and indirectly, and so its $\mathrm{t}$ - distribution value. Leadership influence toward job satisfaction is 0.36 and significant, but if it's through job motivation, the influence of leadership is unknowable impact on job satisfaction because leadership influence toward job motivation is not significant. Leadership influence toward OCB is 0.15 and isn't significant, but if through job satisfaction its influence is significant and as big as 0.36 x $0.51=0.1836$ and if its influence on job motivation, the leadership influence is unknowable its effect on OCB because the influence of leadership toward job motivation is not significant. The influence of organizational climate toward job satisfaction is 0.30 and significant, if through job motivation its influence is significant with the result $1.1 \times 0.3=0.33$ so job motivation variable is important to increase job satisfaction based on organizational climate. The impact 
of organizational climate on OCB and work satisfaction is 0,22 and signifcant.

Based on the descriptive analysis results related to all question items in questionnaire and the result of influence analysis between variables are found some findings need to be discussed, those are: (1) Superior has weakness in motivating his subordinates to be able to do some innovations and creative in working to make work is more effective and efficient. Non academic employees still weak in their on time attendance at campus because of many reasons, (2) Non - academic employees stated that financial and non financial reward doesn't accordance with the job performance, (3) Non - academic employees still weak in showing their altruism, courtesy and sportively. Further, (1) The quality of transformational leadership has no effect toward employees' job motivation, (2) The quality of transformational leadership has no effect toward OCB.

From five factors of transformational leadership those are needed by a superior, according to Robbins \&Judge (2007:382-387) and Northouse, P.G., (2005:174-178), three factors among them are still weak on the leadership at private universities, those are: (1) based on this research is known that the leaders of private universities observed haven't had to behave for affecting their subordinates with strong emotion but positive (2) based on research findings are known that the leaders of private universities observed haven't been able to give inspiring motivation to their subordinates yet, (3) based on research findings are known that the managers or the leaders of private universities observed haven't been able to give inspiring motivation to their subordinates yet.

The presence of employees on campus, either their arrival, existence on work field or returning time haven't shown the presence in accordance with applicable rules. Laziness, feeling bored, saturated with job and traffic jam are two reasons why the employees came late. The employees are outside because of their personal business be one of the other reasons. And also unconditional home time is the cause of why the presence of employees in campus is still constrained. Management should provide a system which is able to monitor the presence of employees in campus. hand-key machine is one of monitoring presence tools, the obligatory to get superior' permission to go out of the campus is also one way to keep employees' existence in campus.

In this research, reward is given by universities to non-academic employees are still weak, it is shown by employees' attitude that still lack of spirit in working because they think that there is no reward if they are success in doing something and in contrast there is also no punishment for them who aren't able to finish their task.

Wage is financial compensation that is so needed at least to fulfill our daily needs. Corresponding to the motivation concept of Maslow, the lowest requirement of an employees are fulfillment of clothes, food, and shelter. Therefore, salary or wage is so needed. It will be different if an employee has been in the highest level of Maslow hierarchy that is self-actualization. In this level, an employee willing to spend their wage to do a specific job. 
Because of this research used nonacademic employees' opinion of private universities, so the need of financial wages is still high. College parties should be able to increase the income, not only from tuition fee, but must be able to get funs of other sources. Through more effective and efficient working process and fund income of many sources, so larger opportunities may occur so significant increase in wage for the employees can be fulfilled.

OCB is a voluntary attitude of someone in doing tasks beyond his responsibilities and duties to sake the progress or profit of his organization. the weakness of three OCB indicators are caused by many reasons as stated by non-academic employees in private universities, such as: (1) This attitude weakness of altruism is indicated by unwillingness to work on the colleagues work who are not present, the reason is they didn't want to interfere with someone's job and other said that they worried to make mistake because it isn't his job and it relate to persons' responsibility. Beside that altruism weakness is shown by giving services to the students, lecturers, and guests with laziness and half-hearted services. Their reasons are they feel disturbed when they are working someone asks for help, because it can disturb their concentration, (2) Weak decency is shown by the non - academic employees by unwillingness to be involve in other activities those are not part of their tasks, their reasons are lazy to do some additional tasks because it will increase the time on campus, and there are some of them refused because of the wage is unbalance with their sacrifice, (3) The weak attitude of Sportsmanship is shown by non - academic employees by their complaints, such as too many tasks to do and sometimes their annoyance had an impact to their services to the students. And sometime their complain is caused by they aren'tinvolved in an activity which will get some wages. Frankly they showed that they don't like and try to find these activities' weakness in order to make as if these activities failed or run unwell.

According to descriptive exposure above that the transformational leadership quality at private universities observed is still low, so the capability to increase employees' motivation is low, too. As we know that transformational leadership seeks to improve relationship that increase motivation and moral. The leader with this type motivates his subordinates to do their job or task better than their subordinates want to and higher than previously thought. Transformational leadership prioritize agreement on what is done by subordinate and promising rewards to be earned when they are able to be achieved, less appreciate the importance of motivating employees. Based on these research findings, where the transformational leadership quality has no effect toward job motivation indicated two alternatives, those are: 1) the leadership implementation is chosen is transactional leadership, and not a transformational leadership as desired by non - academic employees; 2) the implementation of transformational leadership that have been applied by the superiors aren't as desired by non - academic employees expectation. The impact is employees' motivation haven't formed well to work better. So that, increasing work ability as a superior needs to be improved by management through the chairman's guidance or through the participation of leadership trainings.

Research findings showed that universities transformational leadership in South Sumatera 
province have no effect toward OCB. The same as the result findings above which states that transformational leadership has no effect toward job motivation, and it didn't affect to OCB. So that, leadership style which is applied by the superior to the non - academic employees is non transformational style, that is transactional style. Based on these finding results are known that transformational leadership owned by the private universities' leaders are unable to encourage non - academic employees to show their OCB attitude at the universities where they work. Therefore, the previous application of OCB by the employees was not the effect of how the leader or superior are able to plan and control OCB practice, but OCB' application in the universities are supported by other factors. The results supported a research was conducted by Yustina et al (2015).

\section{Conclusions}

After finishing research formulation, research model, research hypothesis, and continued to collecting data process, statistical analysis and discussions of research findings, so in this part is research conclusion.

Transformational leadership of private universities in South Sumatera province was good. The universities leaders have had and given ideally effect and inspiring motivation to their subordinates, however intellectual stimulation to their subordinate is still weak so the subordinates are less motivated to create creative and innovative ideas in increasing their performance.

Job motivation of non - academic employees of private universities in South Sumatera province is good. The employees feel what have been given by university were enough to give them satisfaction so it can motivate them to work harder. However the direction of employees' behavior is still underestimated, it showed that the employees are lack of motivation to come on time to the office.

Organizational climate of private universities in South Sumatera province is conducive. It proves that university has been an effective organization because employees feel that university' party has involve them into organization. These involvement are in communication, team work, and participation in implementation of organizational policies. However reward forms are depended on their performance are given by the universities considered are still less.

Job satisfaction of private universities non-academic employees in South Sumatera province is high. The employees feel that the universities have fulfilled all needs they expected. However, the satisfaction on salary or wage is still weak. It showed that the salary or wage is given by universities still under their expectation.

OCB of private universities non - academic employees in South Sumatera province isn't good, it can be seen from the average value of OCB dimension, which is only two dimension can reach above 4.0. While there are three dimension under this value. The leaders of universities are still weak in motivating their employees to voluntary work beyond their 
responsibility to reach organization' progress and profit. But, the attitude of civilian employees' virtues is considered strong, where they want to follow organizational changes and developments and want to read announcement of management. besides that, careful attitude shown by the employees is high by willing to be on campus in accordance work schedule and speak as necessary in work even phone.

According to causality analysis, known that there are two rejected hypothesis those are 1) there is no influence of transformational leadership toward OCB and 2) there is no influence of transformational leadership toward job motivation. So that, causality research findings which support hypothesis of this research adding new and reinforcing evidence like the previous researches.

\section{References}

Anoop., \& Lokman, M. (2009). Transformational leadership style, market competition and departmental performance: Evidence from luxury hotels in Australia Original Research Article. International Journal of Hospitality Management, 28(2), 254-262.

Castro, M. L., \& Martin N. (2010). The relationship between organisational climate and employeesatisfaction in a South Africa information and technology organisation. SA Journal of Industrial Psychology, 36, 1-9.

Chen, K. (2004). Factors affecting job satisfaction of public sector employees in Taiwan. [Dissertation]. Taiwan: Nova Southeastern University.

Danim, S. (2004). Leadership Motivation and Group Effectiveness. Rineka Cipta.

George., \& Jones. (2005). Understanding and Managing Organizational Behavior 4thEdition, Pearson Prentice Hall.

Hair, J. F., et. al. (2010). Multivariate data analysis. (7th edition). New Jersey: Pearson Education Inc.

Hodgetts, M. R. (2002). Modern Human Relations at work. Ft Worth: Harcourt College publishers.

Luthans, F. (2006). Organization Behavior.Eighth Edition. New York: The McGraw-Hall Co, Inc.

Mariatni, N. S. (2007). Pengaruh Kepemimpinan Terhadap Disiplin dan Kinerja Dosen Universitas Warmadewa Denpasar. Tesis.Udayana: Magister Manajemen.

Mathis, R. L., \& Jackson, J. H. (2003). Human Resource Management. Thomson South Western, United State of America.

Mehboob., \& Bhutto. (2012). Job Satisfaction as a Predictor of Organizational Citizenship Behavior A Study of Faculty Members at Business Institutes. 


\section{Macrothink}

Business Management and Strategy

ISSN 2157-6068

2019, Vol. 10, No. 1

Motevalli, M., \& Chevalier, F. (2015). The effect of work motivation on job satisfaction: a case of farashian pre-cast concrete company in Iran. Int. J. Mgmt Res. \& Bus. Strat.

Northouse, G. (2013). Leadership : Theory and Practice (6th ed.). California: Sage.

Nunnally, J. C. (1978). Psychometric Theory (2nd ed). New York: McGraw-Hill Book.

Organ, D. W. (2006). Organizational Citizenship Behavior. California: Sage Publication, Inc.

Organ, D. W., PodsakoffPhilip, M., \& MacKenzie, S. B. (2006). Organizational Citizenship Behavior. Its Nature, Antecendents, and Consequences. California: Sage Publications, Inc (2006)

Purvanova, R. K., Bono, J. E., \& Dzieweczynski, J. (2006). Transformational Leadership, Job Characteristics, and Organizational Citizenship Performance. Human Performance, 19(1), $1-22$.

Robbins, S., \& Judge, T. (2007). Oganizational Behavior. New Jersey: Prentice Hall.

Smith, C., Kendall, L. M., \& Hulin, C.L. (1969). The Measurement Of Satisfaction In Work And Retirement. Chicago, IL: Rand McNally.

\section{Copyrights}

Copyright for this article is retained by the author(s), with first publication rights granted to the journal.

This is an open-access article distributed under the terms and conditions of the Creative Commons Attribution license (http://creativecommons.org/licenses/by/4.0/) 